\title{
Assessing the strategic alliance between Industrial and Commercial Bank of China and Standard Bank
}

\author{
By Vanessa Eidt \\ Johannes-Gutenberg University, Mainz, Germany
}

Many financial experts, scholars and politicians around the world took notice in 2007, when the Industrial and Commercial Bank of China (ICBC), the world largest bank by market capitalization, announced that it would invest US $\$ 5.6$ billion to acquire a $20 \%$ stake in the South African Standard Bank (SBSA). After all, SBSA is Africa's top bank by assets with a continent-wide footprint. At the same time, the announcement of the deal set off an avalanche of assumptions that this deal "fits nicely" into China's "go global" strategy and was therefore mainly initiated by the Chinese government. Moreover, it was assumed that the alliance underpins a new shift of China's engagement from a resource-seeking strategy to a more knowledge-seeking and strategic-asset-seeking strategy in Africa, and that more Chinese banks would follow ICBC's example, thereby considerably impacting Sino-African relationships in the long run.

Four years after the announcement of the deal, this study intends to evaluate these before-mentioned assumptions. Therefore, it investigates the general reasons and motivations for Chinese banks to enter to the South African banking sector. Within this context, the strategic alliance between ICBC and SBSA is used as a case study, which is studied against the above mentioned broader context to gain a better understanding for the Chinese engagement in the South African banking sector and its importance for the Sino-African relationship in the long run.

The research is based on the analysis of public documents, reports and theoretical papers as well as valuable insights from 13 interviews, which were conducted during August and September 2011 in Cape Town, Johannesburg and Pretoria with key representatives from the South African and Chinese banking industry, the South African financial sector regulatory body, the South African government, scholars, financial experts as well as the private sector. ${ }^{2}$ The interviews were mainly conducted as semistructured, mostly (11 out of 13) face-to-face interviews and some (2 out of 13) via telephone.

\section{According to the research conducted in South Africa, no evidence was found that the transaction was politically driven; rather, it appears to has been foremost business driven.}

\section{Motivation for ICBC to enter into the alliance}

According to the research conducted in South Africa, no evidence was found that the transaction was politically driven; rather, it appears to have been predominantly business driven in the sense that "business leads finance" (Author interview 4; 2011). With the move, ICBC was essentially following its core clients ('market-sustaining strategy') $^{3}$, big state-owned enterprises that have been demanding more global financing. This demand is, especially in the case in Africa due to the nature of business activities e.g. infrastructure and mining projects that both require large investments. In fact, ICBC's clients had demanded ICBC to "come earlier" (Author interview 1; 2011) to Africa than ICBC ultimately did, despite the fact that after the acquisition of several smaller Asian financial companies ICBC entered the South African market relatively early in its internationalization process.

Moreover, the move fits the overall observation that Chinese companies want to cover 
the whole value chain, e.g. in case of the mining business, Chinese companies do not only want to be involved in buying up mines and provide equipment to exploit the mines but also want to finance all these operations.

Additionally, from a long-term strategic-asset seeking perspective, this alliance allows ICBC to acquire invaluable information and knowledge about African markets and how to operate successfully in the African continent in the long run. Last but not least, Africa has a great potential to show significant GDP growth over a longer period due to its currently still low level of GDP per capita. Market-seeking is a long-term strategy on the Chinese side.

Taking into account that ICBC needed to partner with an African bank to enter the African market due to a lack of local knowledge and contacts, SBSA can be considered a natural target in ICBC's search as South Africa has the most sophisticated banking system in Africa (with Kenya, Ghana and Nigeria as next alternatives) as well as South Africa being the largest and politically most stable African economy - commonly perceived as the springboard market into the rest of the continent. Choices for partners in South Africa were not abundant, however, as quite a few of the South African banks had already sought international partners. Out of the four big banks that account for almost $84 \%$ of total bank assets in the South African market as at September 2011 (Banking Association of South Africa; 2011:3) , Barclays had already bought a 56\% stake in ABSA Group in 2005 and Old Mutual was a majority owner of Nedbank. Furthermore, not least from a Chinese perspective, SBSA stood out with its pan-African footprint in 18 African markets as SBSA had historically been following South African outward FDI into other African countries.

\section{It is worthwhile to recall that the partnership was not a hostile takeover, but an alliance sought by both sides.

\section{Motivation for Standard Bank to enter into the alliance}

It is worthwhile to recall that the partnership was not a hostile takeover, but an alliance sought by both sides. Besides needing equity to finance its further growth, SBSA was also looking for strengthening its relationships in the Chinese market, especially in the commodities business. Africa as a continent is particularly strong in commodities and Asia is the biggest buyer in this area, i.e. the goal was to bank the whole global supply chain for commodities. Therefore, SBSA's aim was expressed as not to enter China with a full banking license - SBSA arguably has no competitive advantage there - but rather to strengthen Africa's links to China and other key emerging markets by, for instance, inducing and financing more investments in Africa and globally.

\section{Deal structuring}

The deal had been structured as a $20 \%$ equity injection for various reasons with a winwin situation for all parties. While SBSA needed capital to finance its further growth and the purchase price of US $\$ 5.6$ billion was considered sufficient by SBSA to fulfill this goal, ICBC did not want to enter the African market by running the operations themselves as a controlling stakeholder. Rather, ICBC saw an advantage in adopting a cautious approach with a focus on learning from their South African partner how to do business in Africa. Beyond both transacting partners, it is common sense that South African politicians and the South African Reserve Bank also felt and feel the need to protect their four big banks and do not want a complete sellout of their banking system to foreign investors. 
Moreover, an equity-based cooperation more successfully allows deriving synergies from the banking relationship than a contract-based cooperation. On the one hand, this is due to the fact that the investing bank has a larger incentive to transfer knowledge, superior technology and resources to the target as it also profits from the target's higher dividends and stock price appreciation. On the other hand, through holding two seats in the board of directors, ICBC can oversee and to a certain extent directly influence the strategic direction of SBSA. In general, both parties have better access to their partner's senior management and thereby mutually benefit.

\section{Post-deal cooperation}

Generally, with all acquisitions that are meant to create synergies, the post-deal phase is important to "harvest" the intended synergies. The study finds that there is an extensive cooperation in place on three different levels, namely on a strategic, operational and project level. Strategic cooperation is based on the two seats that ICBC holds in SBSA's board. The cooperation at the operational level is mainly linked to a strategic cooperation committee with different subordinated work streams and workshops. At the project level, discussions focus on specific clients and projects and consequently teams are built around those projects. To a certain extent, ICBC focuses on contributing the funding (especially after IPO, a lot of cash ready for investment had been available), while SBSA knows the African market better and therefore can better "mine" and evaluate projects. Although the USD 5.6 billion purchase price has been counted in the statistics as South African inward FDI, it is in fact largely outward FDI as it is mainly used for post-acquisition panAfrican project financing. Third-party observers have voiced the opinion that more projects could be done if more suitable and profitable investment opportunities existed in Africa and that financing amounts up to date could be higher if the planning process in Africa was faster than it is. While both ICBC and SBSA have fairly complementary operations, they do compete for the provision of funding in some mutual projects and have to jointly agree the amount of financing each party will provide to the suggested project.

\section{Generally, with all acquisitions that are meant to create synergies, the post-deal phase is important to "harvest" the intended synergies.}

\section{Evaluation of the alliance on the transaction level}

It might still be too early to judge the final outcome of the alliance as both parties are taking a long-term view. Assessments will hinge on the level of expectations towards the partnership - and on the timeframe allowed for benefits to be reaped. However several preliminary statements can be made regarding its success. Firstly, mutual relationships between both parties seem to have developed well with extensive mutual knowledge transfer at all three levels of collaboration mentioned before. To date, ICBC has cooperated with SBSA on over 110 projects, while SBSA has been coaching ICBC in the background. In total, as part of the partnership, ICBC has provided total financing of over US $\$ 7$ billion to African countries. It should be noted that the partnership focuses on Africa, but also encompasses projects outside of Africa. While ICBC has expressed its satisfaction with the general return on investment (ROI amounted to $7.7 \%$ after 18 months) (ICBC; 2009), it is also true that the alliance had been formed before the financial crisis and that those pre-crisis expectations have not been fully met as of this date. In September 2010, SBSA expressed its disappointment about the slow revenue flow from the ICBC deal. 
Nevertheless, the deal is considered to be more successful than comparable transactions in the financial sector. From a credit rating perspective, the provision of additional funding by a strong Chinese investor such as ICBC is generally positive for SBSA's credit rating and will also help SBSA to fulfill the more strict capital requirements imposed by the international Basel III banking agreement.

\section{Evaluation of the alliance on the macro level}

As could be read in the press, the alliance, with an investment of this magnitude, was generally seen as a 'vote of confidence' for the future of the African market as it represented the largest single foreign investment by a Chinese firm to date.

The alliance has not had a significant direct impact on the South African financial system, and this can be read either negatively or positively. However to a certain extent, it has led to a more diverse offering of financial products, e.g. through the market entry in 2008 of China Union Pay ${ }^{4}$ that offers credit card products and of which ICBC is a major shareholder and the finalization of the strategic partnership between SBSA and China Union Pay in 2010. Additionally, another outcome of the alliance is the establishment of an online banking platform, which allows Chinese companies to transfer money around Africa. (Alao, Alden et al; 2012:26)

Also, despite the great amount of public attention that the first transaction by a Chinese bank in the South African financial sector had attracted, Chinese companies have been incentivized to 'go global' since around 2002 (i.e. one year after China joined the WTO) and banks like China Construction Bank and Bank of China had already been present in South Africa with offices since 2000. China Export-Import Bank and Everbright Bank had already set up representative offices in 1999. (Brautigam; 2009:74-82)

\section{A key concern in South Africa is job creation; yet investments in the financial sector do not lead to significant job growth.}

A key concern in South Africa is job creation; yet investments in the financial sector do not lead to significant job growth in South Africa. Consequently, local politicians focus on incentives for attracting manufacturing industries. Moreover, the first equity-based deal in the South African financial sector might have also been the last for a longer period of time due to political limitations: South African politicians feel the need to protect the financial sector and want to keep the four big banks in national hands. Furthermore, while all those four big banks might be allowed to have foreign investors ${ }^{5}$, South African politicians seem to want to diversify international minority shareholding; it would be unwise to put all eggs in one basket and have only Chinese minority shareholders.. Besides the South African financial sector, in the future, investments in Kenyan, Togolese, and Nigerian banks could therefore become more attractive for Chinese investors; Nigeria has the largest population in Africa with an estimated 150 million inhabitants.

\section{Conclusion}

The deal of SBSA and ICBC has been in line with the natural progression of China's and Chinese companies' engagement in Africa. The transaction was therefore the next logical step in providing the "financial arteries" (Author interview 10; 2011) for the business activities of Chinese industrial and services companies -no more and no less. 
Surely, even if not initiated by the Chinese government, as with all such large transactions, the deal still can be considered to have had to be approved by all responsible Chinese government bodies. Despite the direct impact of Chinese Banks on the South African financial sector being in scale, the indirect impact from providing finance for projects in Africa, i.e. trickle-down effects, might be large in scale in the long run.

As described above, due to the lack of larger players in the South African and in general in the African financial sector that have the "critical mass" to be a worthwhile acquisition target, potential targets in Africa for Chinese banks can be considered scarce $^{6}$ (in South Africa also due to political constraints). Therefore, it is unlikely to see a 'flood' of similar transactions, especially of this size, in the nearer future in the African financial sector.

\section{End Notes}

${ }^{1}$ The research for this study was conducted during a research stay at the CCS and was generously funded by the Heinrich J. Klein Foundation (Schott AG, Germany)

${ }^{2}$ Due to the sensitive nature of this topic, some interviewees asked not to be named or quoted in this paper: sources and companies are thus anonymous.

${ }^{3}$ SBSA estimates that more than 1500 Chinese companies are operating in the 18 countries where the bank has operations.

${ }^{4}$ China's only bank card association

${ }^{5}$ ABSA Group is already majority-owned by Barclays, ICBC holds $20 \%$ in SBSA, First Rand has a strategic deal-based cooperation with China Construction Bank since 2009

${ }^{6}$ A potential target in Africa for Chinese banks could be, for example, the Ecobank in Togo with a footprint in over 30 African countries. However, Ecobank already signed a co-operation agreement with the Bank of China in 2010.

\section{References}

Alao, Abiodun; Alden, Chris; Alves, Ana Christina \& Meyer, Riaan. (2011). Chinese Financial Institutions and Africa. SAlIA Occasional Paper (103). Pp 26. Online: http://www.saiia.org.za/images/stories/pubs/occasional papers above 100/saia sop \%20103 meyer alao alden alves 21111116.pdf. Accessed: $17^{\text {th }}$ January 2012

Banking Association of South Africa. (2011). South African Banking Sector Overview. Pp 3. Online available: http://www.banking.org.za/. Accessed: $20^{\text {th }}$ January 2012

Brautigam, Deborah (2009): The Dragon's gift - the real story of China in Africa. Oxford University Press. New York, Pp 74-82.

ICBC. 2009. "Cooperation between ICBC and Standard Bank of South Africa Enters Its Prime". Published: 25 May 2009. Online:

http://www.icbc.com.cn/icbc/icbc\%20news/cooperation\%20between\%20icbc\%20and \%20standard\%20bank\%20of\%20south\%20africa\%20enters\%20its\%20prime.htm. Accessed: $8^{\text {th }}$ September 2011

Interview by Author no. 1. Conducted: $9^{\text {th }}$ August 2011 
Interview by Author no. 4. Conducted: $24^{\text {th }}$ August 2011

Interview by Author no. 10.Conducted: $30^{\text {th }}$ August 2011

Vanessa Eidt was a research intern at the Centre for Chinese Studies in mid-2011 while she was conducting research for her Master Thesis. She completed a Master of Business Administration at Colorado State University-Pueblo and is finalizing her second Masters in Business Administration and Anthropology at the Johannes Gutenberg-University in Mainz (Germany) where she plans to graduate in May 2012. During her time at the Centre her research topic was on the Chinese involvement in the South African financial sector and specifically looked into the strategic alliance between the Industrial and Commercial Bank of China and the Standard Bank Group. 嚅 